\title{
Student Protests. Three Periods of University Governance
}

\author{
Joan Ramon Rodriguez-Amat* and Bob Jeffery** \\ Sheffield Hallam University, United Kingdom, *mon.rodriguez@shu.ac.uk, \\ ${ }^{* *}$ r.f.jeffery@shu.ac.uk
}

\begin{abstract}
Exploring the idea of student protests as an autonomous object of research and discussion, this paper leads to the understanding that the transforming role of the university and its governance defines the possibilities for the political role of students. In this perspective, there is a particular constellation of the different forms of higher education governance that provides students with the right and even the responsibility of protesting as politically engaged citizens of the university and of the state. Approaching the transformation of the models of university governance as a set of archaeologically organised states this paper identifies the sequential roles provided to the students and the meaning of their protests and demonstrations. After visiting some antecedents of more contemporaneous student movements and protests, this paper focuses on the UK to explore three manifestations of university governance that can be roughly differentiated as the enduring democratic period that extends from the late 1960s to the late 1980s, the globalisation period that extends from the early 1990s to the mid-2000s and as the post-millennial turn. These periods, embodying three different styles of governance of higher education, not only demonstrate conformity with the political and economic contexts in which they are embedded, they also correspond to particular socio-technological and communicative ecosystems and determine the specificities of the role of the students and their capacity for political action.
\end{abstract}

Keywords: Student Protests, Higher Education Governance, Social Movements, United Kingdom, Information Ecologies

The relationship between students and protests is a commonplace of university life: "Any student community without a protest of some sort on the stocks invites the charge of complacency and will be looking for a grievance" (The Guardian June 1968, quoted in Thomas 2002, 280). This assumption is taken for granted but not unproblematic. Yet even if the representations of students have changed over time, social discourses around university students stress the attributes of youth, rowdiness, rebellion and anti-authoritarianism. These considerations, which will be explored further in detail below, carry implications that echo through university administration and media representations, but can also serve as an explanatory- symptom of a broader scheme of social, economic and political frames.

Indeed, the roles and representations of university students do not stand in isolation from the transformations of the societies in which they are embedded. The changes in the perception of students and their claims relate to broader transformations at social, technologic, economic and political levels, as well as to the changing logic of the varied interests-in-tension that shape university governance. The converse is also true: governance changes serve to reproduce different "models" of studenthood. On occasions, students have been constructed as political actors within the institution or in society, whereas on others students are treated and enabled as consumers. In this sense, whatever current narrative defining the social role of the university modifies the "logic" of student behaviour to the extent that students are provided spaces of identity beyond their own decision-making and performative ca- 
pacity. The constellations of factors are broad enough and complex enough to obfuscate any casual mechanisms that form them and to appear not as linear changes of a teleological nature but rather as epistemologies, instead. Consequently, this article approaches the stages of students' protests from a genealogical point of view (Foucault 1970), according to which the three stages identified form discontinuous archaeological layers instead of as the result of an ongoing, continuous and linear historical process. This is to allow for a holistic view of the definition of the social space of students' protests, and also their nature as information ecologies (Treré 2012).

\section{Students and Protests: State Authority, Market and Academic Oligarchy}

It has been noted that: "[...] the history of Western education is a history of power struggles, and student resistance is as old as the university itself; students developed and used their individual and collective power, defining themselves in relation to the societies and social institutions they fought against." (Boren 2013, 20).

However, even if the drive behind student actions might seem to call for total revolution, "it is wrong to regard the student movement as a revolutionary movement in itself $(. .$.$) 'In the long run these come to an impasse [...] for students do not have real$ power to transform society' (Harman, 1970; 1)" (Woodcock 2013, n.p.).

The university has been part of the European landscape for a thousand years and has transformed in step with broader societal change. In this sense, university governance has changed in parallel to the transformational role of university in society and in national, regional and local economic development. A good example of the recurrent exploration of this issue is the extensively cited systems approach explored by Clark (1986; see for example, Jongbloed 2003, 131). Pace Clark, the changes in the balance between the three dimensions that explain the governance of higher education are: state authority, the market and the academic oligarchy, which in combination serve to modify the position and the value of the students. Later Braun and Merrien (1999) described four models of university governance: the 'collegium', the 'bureaucratic-oligarchic', the 'market' and the 'new managerialism' governance models. The relationship between these four models has also been described by Lazzeretti and Tavoletti $(2006,25)$ as "an antique archaeological site", meaning that they can be approached and explored as differentiated layers overlapping and independent from one another, while keeping in mind that "none of the different epochs seems to be finished. Traces of each level refract upon the present making them really contradictory, complex and remarkable institutions" (Lazzeretti and Tavoletti 2006, 25).

The changes in the governing logic of universities also involve student unions. They have historically played a fundamental role in student mobilisations. Despite the changes in both the role of students' unions within the universities or in their juridical form, their value and continuity as political agencies for the collective will of students can be also perceived in the representations of students as protestors. These have been approached in the academic research from multiple angles: enlightenment and co-optation; authority and youth; networking and location. For instance, social psychologists like Smelser (1968) focused on the continuity between youth, students and protests by arguing that rebellion against the institution takes the place of rebellion against the father; or a "biological urge of the adolescent to assert himself" (The Sun 2 June 1969: 8)" (Moore 2006, 5). Indeed, the generational struggle has dominated the literature on student protests in the sixties: "for the first time, large numbers of young people challenged the decisions and attitudes of authorities and members of older generations" (Thomas 2002, 278). Other approaches instead focus on the conditions of the university that foster the politicisation of students, for example Marsh 
(1977) argued that the university instils particular values into students: providing a space for the fermentation and tolerance of new ideas. Universities provide not only potentialities linked to social networks and the ability to network, but allow for the development of a 'critical mass' of politically engaged young people (Crossley and Ibrahim 2012). Recent developments of these perspectives have explored the role of student societies in constituting networks: "[...] to understand the precise political dynamics of these protests, we should focus on the university campus itself and how it is conducive to (indeed, facilitates) mobilisations because of its very network-like structure and those of its students' union and political societies." (J. Ibrahim 2011, 416).

And even more; not only physically enabled campus networks but also those virtually constituted by social media (see Maireder and Schwarzenegger 2012, Brantner and Schwarzenegger 2012) and appropriated by those with a surfeit of free time: "Students are often at the cutting edge of social radicalism, since they alone possess the sometimes volatile combination of youthful dynamism, naïve utopianism, disrespect for authority, buoyant optimism and attraction to adventure, not to mention a surplus of spare time. They perceive themselves as the leaders of a future generation and are often over-eager to thrust themselves into the task of reshaping their society." (DeGroot 1998, 4).

Nonetheless, the link between students and protests also extends to the trope of student protest as a core component of wider revolutionary struggles. As in France in the sixties, when they were strongly related to the role of the working class and the labour unions in joining the claims as Les Enragés: "these protests were, for some people at least, the possible vanguard of a future workers' revolution" (Thomas 2002, 283). These arguments are part of a burgeoning field of research on student action, social movements and protests. However, this tradition and discussion cannot be extended here. It is more urgent to deal with the communicative environments and with the transformation of student protest over time.

Student protests are enabled by participants communicatively networked and in interaction with an environment of media reports and police activity that has changed over time. This techno-communicative environment must be understood as extending beyond the media that construct and represent the students, their claims and protests, or the disorder that sometimes results - that is, beyond the traditional definition of media. Actually, this milieu also includes the means that the students use to interact among themselves to create networks, and with their environment, higher education institutions, governments and other collectives and political actors depending on their claims, range and intentions. As Treré (2012) has contended, the environment of student protests is formed not only by the contents of the communication - the languages, the representations and the interaction between actors - but also by the ecosystem of technologies and devices as well as by the configurations of space and place that result from the (re)structuring of urban public space (Rodriguez-Amat and Brantner 2014) or the role of media in propagating protests waves across space and time (Andrews and Biggs 2006).

There is a complex mesh of factors that explain why student protests remain under perpetual transformation. It is impossible to discern a line of historical transformation that identifies stable elements. As J. Ibrahim notes, "[...] student protest movements are not homogeneous; they vary in size, cultural identities, resources, values and grievances; each national or local case must be examined on its own merits and theoretical frameworks established from those specific empirical examples." (2011, 419) 
Having said that, on examining chronologies of student protests and the changes in the university governance (Boren 2013; Ruegg 2010), three major moments can be perceived. This article therefore prefers to explore these histories through Foucault's metaphor of the archaeology of knowledge (1970); that is, by identifying three layers that correspond to three logics of university governance. This genealogical approach (Foucault 2002; Foucault 1970) highlights the rationale within each one of these three epistemic moments. The resulting epistemes of university governance distinguish three positions for the students: reducing the diverse collective of students to a single homogeneous entity is part of the epistemic machinery of order; and this includes a certain form of university, a certain set of practices, of values and of students. Stated thus the claims of students understood as politically engaged versus the claims of students understood as lazy consumers or as users of the university have scant regard to the perspective of the students, but rather represents that of the institution that is constructing them.

\section{Student Protests: Three Stages and an Antecedent}

The historical explorations of Boren (2013) and Ruegg (2010) allow for multiple ways of organising a chronology. During the last century, universities have changed forms and roles within the also changing state structures and the transforming student organisations and their communicative environments. Aware of the diversity of political environments and of policies involving student fees, access to university, understandings of higher education and regulatory frames between countries, this article focuses on the United Kingdom, noting, as examples, cases from other countries. Three grand moments help explain the transformations of the university and student bodies in the United Kingdom. The following section is organised accordingly, with a prologue describing the first student protests in history.

\subsection{Once Upon a Time: Students}

Universities originally referred to informal guilds of scholars and their students; "the word universitas signalled only a collection of students, similar to the guilds of weavers or carpenters" (Boren 2013, 8). The notion of students as a community was therefore not originally a principle that altered the functioning of the city until the university began to develop its own autonomous institutional structures. This is the period that corresponds loosely to what Braun and Merrien (1999) called the 'collegium' governance model. "According to this concept the "community of scholars" would administer its own affairs, having few dealings with bureaucratic officials" (Baldridge $1971,4)$. The insertion of scholarly communities into cities during the European Middle Ages (Bologna in 1088, Oxford in 1096, and Salamanca in 1134) invited the growth of economic strategies to exploit students with higher rents and higher prices. Students were visitors, strangers to the city inhabitants and often (as today) of a higher social class. Not only had they different habits and routines but they were also easy to distinguish and often accused of uncivil practices. Students were not invested "in the towns in which they studied; they felt neither personal nor social pressures to conform to their foster towns' notions of proper behaviour or proper respect for person or property" (Boren 2013, 10). Differences emerged sometimes in the form of the so-called 'town-and-gown' clashes (Ward's book of days 2006; Miller 1993; Headlam 1912) centred on room rents, manners and the quality of wine served at inns. These disputes were typically resolved in favour of an increase in the power of the university over the city: the prestige of the elites in the academe and the economic opportunity for the growth of the city, forced settlements upon the townspeople that granted se- 
curity for the students and exemptions from municipal control for the institutions of the university. These social clashes carried major economic, urban and political implications.

The associations of students were politically relevant and acted as transformative forces, for instance in the $16^{\text {th }}$ Century Renaissance and Protestant Reformation, shaping the intellectual debates (Boren 2013); or in the $19^{\text {th }}$ Century, when the demonstrations and student organisations or Burschenschaften played a role in the formation of the German state, articulating the demands for national unification and the writing of the German constitution. Perhaps the most consequential event of the early twentieth century was also related to student protest: the assassination of Prince Franz Ferdinand of Austria was committed by the student militant Gavrilo Princip in Sarajevo, triggering the start of the First World War.

The public expression of students is linked to key events in world political history; it would therefore be unfair and historically false to identify the students as a political body that has only emerged since the mid- $20^{\text {th }}$ century. Nonetheless, the aims of this article are particularly concerned with the transformations of students as political actors in protests since the 1960s.

\subsection{Enduring Democracy 1965-1985: University and the State Control}

The explosive combination of a generational conflict of baby boomers, the cultural revolution, the growth of youth subcultures and the technological changes that enabled the visualisation of what can be considered the first mediated protests, has made the sixties the epitome of student protest for generations to come (Y. Ibrahim 2010). Yet this only marks the beginning of an epistemic moment that extends over two decades of student organisation and of world geopolitical events; shaping a model of university governance. Efforts - and struggles - to steer the university by emulating the possibilities of the state and adopting a logic of democratisation were evident, as was happening with the state authorities around the cold war capitalist block. Protests were seemingly linked to the geopolitical world events and to national policies relating to labour or gender and race, rather than university business per se. The sense of solidarity positioned the university - and the students-citizens - as actors for altruistic political claims related unacceptable events on the world stage, such as the case of British students protesting against the Vietnam war (Thomas 2002). However, the university was struggling with a generational change within its disciplinary walls. Students were citizens practicing and claiming rights both outside and inside the university. There are examples of these protests from around the world, ranging from France to the United States, Germany to Mexico, Australia to Japan.

In the United Kingdom, there were street demonstrations and sit-ins. Probably the most significant of them was held in protest at the Vietnam War at the American Embassy in London on October $27^{\text {th }}$ of 1968. It gathered around 20,000 demonstrators in Grosvenor Square. The organisation was done by "an ad hoc committee that was comprised of a variety of groups, with different political aims" (Ibid., 287). Perhaps the most important outcome of this demonstration was a sense from the establishment that it had been caught off-guard, which led to the creation of the covert Special Demonstration Squad - a policing squad aimed at the undercover infiltration of UKbased protest movements (Evans and Lewis, 2013). During that period a wave of sitins spread across the country affecting "higher and further education institutions [including] those at LSE, and Birmingham, Manchester, Leeds, Liverpool, Bristol, Keele, and Leicester Universities" (Thomas 2002, 278). 
The centres of reference for the student protests during the period have been however France for the intellectual revolt and the rebellion in the USA against racial segregation. On the back of a combination of sophisticated statements of political, social and economic needs, students at the University of Nanterre, Paris, calling themselves Les Enragés, began protesting against the hegemonic capitalist and conservative/reactionary values (Perry 2008) of authoritarianism and the consumer society. Concurrently, in the USA, groups such as the Student Nonviolent Coordinating Committee led campaigns against racist segregation in the face of violence by the state and reactionary interests. In Germany, the killing of a student protestor by police in 1967 also raised intensive resistance, and on October $2^{\text {nd }} 1968$ the Mexican army opened fire with machine guns on massed student protestors at the Plaza of the Three Cultures. In Japan, armed protestors occupied Tokyo University forcing the university president to step down.

In this period, a new generation of post-war youth were entering adulthood under a whole new regime of consumption, expression and cultural identity mid-way between the readymade productions emerging from the media industries and their own negotiated performances. These young citizens were "members of a generation that had enjoyed unprecedented access to wealth, opportunity, education and employment" (Thomas 2002, 279). These youngsters found themselves caught between three imperatives that included a still exotic but growing globally market driven cultural industry; an effort to maintain social and traditional values embodied by parental and other regimes of authority, including the teaching authorities; and the urge for a double shift that would enable them to grow their own democratic views free from the consumerist ethic and from the pre-democratic authoritarian mode of education: 'Marcuse in particular singled out students as the social group which was sufficiently removed from the corrupting influences of capitalist society to be able to challenge and undermine it' (Ibid., 293). This triple tension is well represented by what university was: an old institution of authoritarian and patronising structure that did not apply democratic principles to itself, and without the capacity of accommodating a growing number of socially diverse students. The values of change, rights and innovation were in tension with those of the university as a space of discipline.

Even if according to the National Union of Students (NUS), the students in the United Kingdom suffered from apathy in the sixties (Thomas 2002), they were considered to be the promising generation of baby boomers born in the post-war peace with a responsibility for extending democratic values, universal human rights and the welfare state principles of solidarity and tolerance of diversity. The state contributed by changing the structures of the university governance: facilitating the autonomous organisations of students and by incorporating the students in managerial organs: "In the months afterwards, Essex students won representation on most university committees and over fifty per cent representation on several which directly concerned student interests" (Hoefferle 2012, 9:86).

Those student movements of the enduring democratic moment were (in this instance) not demonstrating for revolution but as part of a general drive for a progressive improvement or transformation of the institutions in accordance with democratic rule. The techno-communicative ecosystem also embodied the tensions between ideological and generational clashes. From one angle, the established media fabricated some significant myths in its representations of the protests: short-sighted understandings premised on the fear of absolute revolution (sometimes expressed as contagion from France) and the common interpretation that protests were caused by permissive parenting (see Parkin 1968). But as Andrews and Biggs (2006) put it, 
"news media were crucial for conveying information about protests elsewhere" even if they did not intend to encourage them. The novelty of the protests was reported with alarmism in the press: The Daily Telegraph (March 19 $\left.19^{\text {th, }} 1968\right)$ stated "there were moments when the crowd seemed bent on violence as an end in itself" (Thomas 2002, 289). However, the demonstrations and protests were "more complex and less threatening than the media image would seem to have allowed" (Ibid., 290). At the same time, the students creatively expanded the communicative ecosystem by incorporating some media to their expressive action: "Although the Free University and occupation were carried out peacefully and seriously; at other times, the protest resembled a carnival of sorts. Evenings were filled with music and dancing, vivid artwork and graffiti sprung up around campus, and television crews and even a film crew established themselves on campus to document the ongoing drama." (Hoefferle 2012, 9:85).

Students themselves were either using the student newspapers or creating communicative structures under the forms of independent and ideologically combatant political and cultural newspapers like the Black Dwarf in the UK (see Hoyland 2008 and Thomas 2002), without ever taking the eyes off the coverage by the mainstream media.

These complex circumstances redefine the position of the students within the new university governance frame. The principle implemented at the university, aiming at more democratic forms and for equality of access under a transparent meritocratic framework, sets conditions for the profile of the students as political actors in permanent tension; permanently asking for fairness, clarity and intellectual worthiness. Students born from the new university logic were also engaged citizens aware and reactive to global geopolitical injustices.

This idea of the student as a citizen (of the university-city, agent of socio-political justice and equality, and citizen of the world) mirrors well the idea of a University under the governance regime of what Van Vught (1989) calls "state control" (see also Jongbloed 2003). That is, the state granting universities and investing in them to further its own growth and development; and attributing to the students their role as claimants upon and actors within the governance system.

A common ground for the universities from the late 1960s and those of twenty years later can appear to be reductive of the multiple and complex transformations that took place in particular countries and across universities in the Western world; nevertheless, the opportunity of framing the period in the terms suggested here helps in understanding other aspects of the wider picture. For instance, challenging the twin myths of revolutionary students and the patronising forms of othering of the conservative narrative.

\subsection{Globalisation 1985-2005: University and State Supervision}

Obviously, there is no singular event that establishes a change of paradigm; but multiple developments unfolding throughout the eighties crystallise during the early nineties. As symptomatic problems and the readjustments of the previous decade give way to important shifts in university regimes and the roles of the state all over Europe - but particularly in the United Kingdom -the results are significant changes to policy. . Several Acts modify the university environment, aligning the institutions, their governance and the environmental conditions around a logic the features of which could be already perceived during the last half of the eighties. This section explores the major features of the new episteme of a university governance model that turns the university, increasingly autonomous now from the state institutions, towards what the 
Clark (1986), and Braun and Merrien (1999) models would name 'the market'. This is a knowledge-for-the-market driven system in which the university provides a workforce for a growing labour market, and produces ideas for the economy and for the state.

A chain of Acts modifying the statuses of the United Kingdom universities (1988, 1992 and 1994) illustrates well this change of paradigm. The Education Reform Act of 1988 created universities, polytechnics and college funding councils and gave power to the Secretary of State for Education to direct funding councils and debarred University Funding Councils to encourage universities to raise external funds (Richards 1997). Furthermore, in 1992 the "Further and Higher Education Act" abolished the binary line between universities and polytechnics, incorporating 35 new universities that allegedly "have done the heavy lifting in terms of overall student expansion and in widening participation for students from "middle England, working-class homes and ethnic minorities" (Scott 2012, n.p.). The Act was considered part of a process of "democratisation" of the university access that increased dramatically the numbers of university students frontally challenging the former university structures of labour and of organisation. The 1992 Act also created the national unitary funding councils, one for England (HEFCE), one for Scotland, and one for Wales. These 1988 and 1992 Acts, prior to the Higher Education Act of 1994, underline a change of position of the state as a major funding entity of the University system and incorporates a logic of competition and of external funding that will progressively grow towards 1998, when tuition fees are first introduced in the UK.

The policies implemented also reached the role and forms of the student unions. The increase in the number of students parallels the stepping up of efforts to depoliticise their action. Reforms affecting the student unions work as attempts to eliminate spaces of autonomous political activity. It is a long path symptomatic of the end of the democratic expansion and cementation of the grip of the 'New Right' upon western states. In 1984, legislation in the UK concerning free speech on university campuses outlawed the National Union of Students' "No platform for Fascists" policy (Richards 1997). In 1985 courts ruled illegal two donations by the Student Union of the Polytechnic of North London (U.K) to support the miners' strike and for the relief of an Ethiopian famine. In both cases it was established that since the universities they were attached to had charitable status, the unions themselves also had this status. Furthermore, the UK Education Secretary John Patten, pushed to end the closed shop system of Union recruitment forcing them to ensure membership of all students who volunteer. These were not only changes in the funding structures of the Union but also, "the charitable status of student unions, though largely taken for granted now, is intimately linked to a political agenda to erode solidarity between students and workers in struggle" (Swain 2011).

Student unions still had an ambiguous status, lacking uniform structures and organisation. But the Education Act of 1994, aimed at dampening down student protests, contributed to the transformation of the culture of student unions from campaigning bodies to service providers. Slowly, the services side of most unions - bars shops night clubs - increasingly tended to outweigh the representative side, both in the agenda of the union and in the way it is viewed externally: "The corporate aspect gives rise to a permanent apparatus of full-time unelected union employees, whose interest lies in not rocking the boat" (Ibid.). The changes in funding and role of the unions impacts their communication patterns: now they need to gain presence within the community of students to finance their more complex structures as employers 
rather than lobbying at the political extra-university level. These changes echo also in the ways unions communicate and embody the university students' interests.

In June 1987, the European Commission adopted the European Region Action Scheme for the Mobility of Students. Despite the resistance of the most powerful European countries (France, Germany and the United Kingdom), the Erasmus Programme would go ahead with the strategic help of the largest transnational, interdisciplinary student organisation in Europe, the Brussels-based Association des États Généraux des Étudiants de l'Europe (AEGEE). The ERASMUS Programme embodies a major turning point in the systems of university ruling. The idea of exchanging students across Europe fits as part of the initial European project of building a union of states premised on peaceful cooperation and the free movement of capital and labour. The exchange of university students, then, goes beyond the strictly educational opportunity and reaches a symbolic level of European solidarity, egalitarianism and cultural identity (Tamcke et al. 2013) that will be a first step towards the construction of the European Higher Education Area (EHEA): "the basic idea behind all educational EU-plans is economic: the basic idea is the enlargement of scale of the European systems of higher education, [...] in order to enhance its 'competitiveness' by cutting down costs" (Lorenz 2006). In preparation to the first European student programs, major university reforms also take place outside of the UK. For instance, in Spain, the numbers of university students doubled within a decade, from 788,168 students in 1984/85 to 1,445,322 students in 1994/1995 (Rahona Lopez 2008, 40). Also in Germany, considered to be a late arrival in terms of recent higher education reforms (Wollter 2004), the increase in the number of students after reunification drove a transformation of the higher education system during the nineties that would develop in the direction of increasing the logic of competition between them (see Wollter 2004).

Communicatively speaking, this period marks a transitional and paradoxical moment combining the expansion of the still expensive personal computer and the increased access of students to digitalised and interconnected contents with the isolation and reduction of their strength as a collective. The ecosystem of communication networks included analogic media with a strong dominance of the audio-visual news industry in Europe owned by national broadcasting corporations or by global conglomerates; in parallel, the independent strongly nationalising presses and later the first mobile phones and computers accessing the internet. Basic computer-user literacy spread across the students' curricula and universities invested strongly on granting technological access to the increasingly demanding students. In this landscape, the students' publications become a residue unable to afford powerful and expensive audio-visual infrastructures.

In spite of the structural and fundamental differences between the countries, there is a general perception that the changes have a clear direction: "a retreat of the state from a very detailed administrative control system to cautious institutionalisation of a new triangle of steering, relying on goal setting and contract-management at different levels, strengthening the executive and planning functions of the university management, and an elaborate system of output and performance evaluation in research and teaching." (Wollter 2004).

The European higher education system saw reforms clearly oriented towards the autonomy of the universities, bringing a state supervision model into place. This new governance model of universities drastically shifts the position of students. The once liberal educational values and the inculcation of a capacity for critical thinking within the university context (see (Marsh 1977) may have shaped students into a group 
aiming to participate in the university system as students-as-political actors; but the increasingly commodified system demotes students to a position of merely celebrating the chance of having earned their path to a university education valued only in terms of the titles and income that can be earned as a result.

\subsection{The Millennium Turn: An Understanding of the Suicidal State}

A little less than a decade ago the world found itself in a new fundamental struggle, one that is not yet over. The foundations of capitalism shook with a financial crisis caused by the global operations of fictitious capital and a debt charged to civil societies through their national finances. The state has become the laundering device that transformed the private debt of a capitalist elite into a public debt, forcing exceptional/permanent measures of budget reduction, attenuation of fundamental rights and social tensions emerging as resurgent right wing parties, xenophobic measures led by supposedly social-democratic parties and unprecedented levels of unemployment, precarious labour and regulatory enforcements that militate against any capacity to respond. Universities and higher education institutions live these struggles in their very bones when the funding is systematically cut, wages, terms and conditions are forced down, and students are taxed through increased fees and loans that turn their university dream into a life-long payback nightmare: "They are being told to bear the burden of an economic crisis that they didn't create" (Power 2012, 419).

In the derived university governance constellation, a financial vector has grown dominant by turning universities into major agencies of debt, in which knowledge is depreciated in front of a marketing service whose only promise is to ward off serious unemployment. If in the previous paradigm, the marketisation was already feared and students were preparing for real jobs while crossing the university toll on knowledge; in the current situation the university becomes a service for employability that dismisses the contents of the knowledge by dedicating increasing amounts of the curriculum to polishing $\mathrm{CVs}$, training for interviews and simulating employability opportunities. In this context, aside from whatever expertise, students learn to become a new precariat. As Judith Butler puts it: "The precariat may not have jobs at all. They may have a job and lose a job in quick succession. They may be transient labourers. They may have shelter and lose it the next day. The future is radically unpredictable" (Soloveitchik 2016). And this is the experience of the millennial students. They now exist in a world where expectations of future security and even affluence have given way to an onerous debt-mountain, as:"[... f for the first time in living memory, the whole class of graduates faces a high probability, almost certainty, of ad hoc, temporary, insecure and part time jobs, unpaid 'trainee' pseudo-jobs deceitfully rebranded 'practices' - all considerably below the skill they have acquired and eons below the level of their expectations"." (Bauman, 2012, quoted in Giroux 2013, 11.)

As Swain (2011) notes, gone are the days where students could be said to be a privileged section or society, or at least this is the case, we may add, for a majority of students, given the increasingly differentiated experiences of higher education that have been the logical consequence of marketisation and competition. This marginalisation is evident not only in the poor jobs to which students are consigned following graduation, but also those they must take to 'pay their way through' university, as well as the increasing difficulties they face in obtaining housing. As seen, for instance, in the student rent strike in London in May 2016 (Taylor 2016). The economic imperative driving the expansion of $\mathrm{HE}$ of the previous decades has instigated an increase in the uptake of vocational degrees (UCAS 2007), which, coupled with the employability agenda, prioritises the needs of industry for such universities. And this 
is implicit in policy: "the massification of HE is designed to support industry by providing a "better" workforce" (Molesworth, Scullion, and Nixon 2010, 279). Parallel to the transformation of the university governance drives, the student population with access to higher education has multiplied spectacularly. "widely surpassing, in Western Europe, one-third of people interested in the first university enrolment" (Lazzeretti and Tavoletti 2006, 19). In the UK, the number of higher education students has increased from 600,000 in 1971 to 2.5 million in 2009. (BBC News 2011). This reflects the restructuring of an economy requiring an increasingly educated workforce (Swain 2011). An avalanche of policy documents also constructs higher education only in terms of profit making, efficiency maximising entities; set against a growing critical literature that opposes the transformation of students into consumers.

The geo-political tensions produced by the crisis of capital have led to protest movements emerging in variety of places, with the reference point being the global anti-war demonstrations of the $15^{\text {th }}$ February 2003 that engaged more than 600 cities, and is considered 'the biggest protest ever to have been held in one single day' (Walgrave and Verhulst 2003), even though it was ignored by political elites (Tharoor 2013). Student participation has been a constant feature in these movements to the point of becoming fundamental forces in the massive protests against what have been called Austericide measures, like the Spanish Indignados movement of 2011 (Toret 2013); or protests such as the Vienna \#unibrennt and \#audimaxismus in 2009, against the implementation of Bologna policies in the Austrian universities (Brantner and Schwarzenegger 2012), or the Millibank protest in the UK in 2011 (Haywood 2011).

In the meantime, the British attempts to curtail the power of student unions during the last decade led to a further Act of Parliament in 2006. The Charities Act forces the Unions to become registered charities, further shifting the balance away from activism. Even later, in 2010 the Charities Commission dictated that: "union funds cannot be used to promote or support campaigns on matters which may be of general interest or concern but which do not affect members of the union as students" (Woodcock 2013). Furthermore, the state is rapidly formulating measures that criminalise the right to protest. Following the occupations of 2011, the government of the United Kingdom turned its attention to squatting legislation that would make residing in both unoccupied buildings and educational institutions a criminal, rather than a civil, offense (Power 2012, 414). Indeed, the efforts to spread the de-politicisation and criminalisation drives generalised during the 1990s and 2000s seemed to shift with the occupation at Middlesex University in May 2010, following the announcement of the closure of the award-winning philosophy department (Swain 2011). Protest reached a significant crescendo later that year, when students protesting at the tripling of tuition fees to $£ 9,000$ per year occupied the Conservative Party headquarters at Millbank in November, breaking the illusion of apathy. Students were supposed to be lazy and apolitical; Britain was supposed to be the home of moderation, non-confrontational political action. Millbank shattered these ingrained myths (Haywood 2011, 69). Without dismissing the specifics of each case and country, there is a growing perception that a process of re-politicisation of students started during the last decade, experimenting with new forms of action, as well as provoking new forms of reaction.

The specifics of the British tuition fee protests have been explored at length in the literature and for some, this feels almost like a return to the student protest of the 1960s (see for example, Bloom 2012; Dean 2015; J. Ibrahim 2011). Alongside this, there is also a perception that something new inhabits these protests, such as the 
role of social media in raising consciousness and coordinating action. And perhaps most strikingly, these student protests have been able to mobilise networks from around the globe: the impact of \#yosoy132 has been global, as well as the Printemps érable actions of 2012 in Québec or the Chilean winter (2011/13). These examples show the creative and extended networks that student protests have built, thanks to the online possibilities and the use of social media.

The information ecology (Treré 2012) of the students' activism is fundamentally composed by social media, the use of mobile devices, and integrating physical and virtual activity as part of the protest. The information ecology lies somehow at the heart of these novel social actions. Now, in the hands of the students, their protests expand and conquer virtual spaces as well as the physical spaces of the university lecture theatres. But also these novel virtual-physical actions might lead to technooptimistic biases far from being empowering or liberating for the protestors. Such optimism is evident when scholars "have argued that social media had created the basis for the emergence of new, horizontal forms of social organizing, which would overhaul existing political and economic structures" (Barassi 2016). But critical scholars raised their eyebrows too: whatever smartness and shared creativity impelling citizens to spread online and to articulate as social movements seems outsmarted by structures of power. For example, as Treré has demonstrated, the policing of the Mexican student demonstrations \#yosoy132 was characterised by "authoritarian engineering", including "the algorithmic construction of consent and the artificial sabotage of dissent [demonstrating] that there is nothing inherently democratic in digital technologies" (Treré 2016, 136). Indeed, scholars like Andrejevic (2016) and Barassi (2016) write about datafied citizens, to insist that, after all, the internet and the social software platforms are the ring-fenced territories of private companies, more interested in cropping our data while evading taxes than in liberating the oppressed.

Also, similarly to the UK, measures to criminalise protests and to track social media, confronting consolidated citizens' rights to protest and of freedom of expressions, have been put into place. But also, the draconian reduction of university budgets and the steering of financial gains are obtained through the cutting of the rights of university staff and by inviting the students, now cursed into tamed job seekers, to fund the university through ever higher fees. This system built on personal debts will force the students to keep their heads down and to take whatever work opportunities to pay it back, rather than using their glorious time and energy to improve the world: "Youth no longer occupy the hope of a privileged place that was offered to previous generations. They now inhabit a neoliberal notion of temporality marked by a loss of faith in progress along with the emergence of apocalyptic narratives in which the future appears indeterminate, bleak and insecure." (Giroux 2013,10)

This picture reduces the position of the university to an accomplice of an economic system that is not only mutilating the state's role as equaliser of social differences but, instead, is actively contributing to undermine its own earned role of maintaining an acceptable social contract. The state dismantles itself voluntarily to make room for ultraliberal policies and to enable the global financial structures to take over the regulatory frames. This is something for which the concept of a suicidal state (Giroux 2012) seems apt, even if Foucault and Virilio referred to it in slightly different terms.

\section{Concluding Remarks}

This exploration of a genealogical structure of the university governance and the mirrored role for the students and the student unions within the epistemic frame is a signpost towards a broader research program. There are numerous possibilities of 
using this initial theoretical frame as a reference for the understanding of the transformations taking place in the universities of other countries, or as a comparative tool that enables both the temporal and the geographic contrasts. Also, this initial model leaves some room for improvement at the conceptual level, for instance by exploring to what extent this model needs to be modified when applied to other contexts or even if the model holds when specifically approached from other perspectives. For this, more research is necessary and welcome. Certainly, the next area of exploration that would help consolidating this model would be to expand what has been barely drafted in this piece: the possibilities of an analysis of the techno-communicative ecosystems in each one of these periods and the extent to which the communication networks can enable an autonomous (political) reaction or identity growing from the student collectives, or if instead, the informational fields have to be understood as embedded in the governance logic of the university.

For now, however, the contribution of this paper hinges on the notion that university students are to be understood mostly as the product of the material relations of society, and, crucially, the university governance regime, rather than as the expression of a substantial identity. This means that instead of intending to give them a space, a claim and a political role of their own, students and student associations can only be explained as part of the broader context by which the university is governed in relation to the tensions between dissenting interests. That is, state authority, the market and academic oligarchy. The articulation of these three factors helps also to explain the transformation of the core higher education governance systems and by extension, the role provided to the students, to the student associations and to their protests.

Through an exploration of the changing models of higher education governance the paper has shown that three main layers can be discerned: the enduring democratic period, the globalisation period and the Millennium turn. These three periods correspond, not only to differentiated configurations of the three factors of governance but also provide different roles for the students and the student associations. Whereas the first period constructs students as citizens that are enabled to engage politically both at the university level and at the state level, and in which the university seems to emulate the possibilities of the state in adopting a logic of democratisation; the second period constructs students as consumers and as earners of knowledge and degrees of an integrative university system that grows in numbers and in networks for the final achievement of a job. During this period, the popularity of university and the possibilities of employment at the end of the academic circuit, builds cohorts of students rather happy with their own possibilities. Knowledge seems thus to lead to the way of industry and the graduates can actively contribute to the development of the economic system. Finally, in the third period, as financial structures increasingly dominate the economic vector, knowledge is depreciated and the students are shaped for the precarious conditions of a work system that does not need the university knowledge but uses individuals bent at the disciplined capacity for the tolerance of uncertainty. In this context, the software commanded possibilities of social interaction might have led us to believe that the students earned some new capacity for protesting, for interacting and for organising; however, the governance model drives the university towards a position of agency that connects students to a financial labour system that favours a profit-making logic, feeding from progressively more indebted individuals. The options for protest are as scarce as the skills of the graduates endangered by a labour system that ultimately discredits university degrees 
(Ferenstein 2014). Yet, as recent rebellions demonstrate, the possibility of action has not yet fully extinguished.

\section{References}

AMSU, Association of Managers in Students Unions. 2003. The Law Relating to Students' Unions and the Responsibilities of Elected Officers as Trustees.

Andrejevic, Mark. 2016. Theorizing Drones and Droning Theory. Drones and Unmanned Aerial Systems, edited by Aleš Završnik, 21-43. Cham: Springer International Publishing. http://link.springer.com/10.1007/978-3-319-23760-2_2.

Andrews, Kenneth T., and Michael Biggs. 2006. The Dynamics of Protest Diffusion: Movement Organizations, Social Networks, and News Media in the 1960 Sit-Ins. American Sociological Review 71 (5): 752-77. doi:10.1177/000312240607100503.

Baldridge, J. Victor. 1971. Models of University Governance: Bureaucratic, Collegial, and Political. http://eric.ed.gov/?id=ED060825.

Barassi, Veronica. 2016. Datafied Citizens? Social Media Activism, Digital Traces and the Question about Political Profiling. Communication and the Public 1 (4): 494-99. doi:10.1177/2057047316683200.

BBC News. 2011. Graduate Unemployment at Highest for over a Decade. BBC News, January 26. http://www.bbc.co.uk/news/education-12286264

Bloom, Clive. 2012. Riot City: Protests and Rebellion in the Capital. Basingstoke: Palgrave Macmillan.

Boren, Mark Edelman. 2013. Student Resistance: A History of the Unruly Subject. Routledge.

Brantner, Cornelia, and Christian Schwarzenegger. 2012. Der Fall unibrennt: Mobilisierung, Kommunikationsverhalten und kollektive Verständigung von Protest- und Kampagnengemeinschaften heute. SWS-Rundschau 52 (3): 227-48.

Braun, Dietmar, and Francois-Xavier Merrien, eds. 1999. Towards a New Model of Governance for Universities?: A Comparative View. London; Philadelphia: Jessica Kingsley Publishers.

Cammaerts, Bart. 2013. The Mediation of Insurrectionary Symbolic Damage: The UK 2010 Student Protests. International Journal of Press-Politics 18 (4): 525-48.

Clark, Burton R. 1986. The Higher Education System: Academic Organization in CrossNational Perspective. University of California Press.

Crossley, Nick, and Joseph Ibrahim. 2012. Critical Mass, Social Networks and Collective Action: Exploring Student Political Worlds. Sociology, 38038511425560.

Dean, Jonathan. 2015. 'Angelic Spirits of "68": Memories of 60s' Radicalism in Responses to the 2010-11 UK Student Protests. Contemporary British History, October, 1-21. doi:10.1080/13619462.2015.1099438.

DeGroot, Gerard J. 1998. The Culture of Protest: An Introductory Essay. Student Protest, 311.

Evans, Rob. and Paul Lewis. 2013. Undercover: The True Story of Britain's Secret Police. London: Guardian Books.

Ferenstein, Gregory. 2014. Why Google Doesn't Care about College Degrees, in 5 Quotes. VentureBeat, April 25. http://venturebeat.com/2014/04/25/why-google-doesnt-care-aboutcollege-degrees-in-5-quotes/

Foucault, Michel. 1970. The Archaeology of Knowledge. Routledge. 2002.

Foucault, Michel. 2002. The Order of Things: An Archaeology of the Human Sciences. Psychology Press.

Giroux, Henry A. 2012. The 'Suicidal State' and the War on Youth. Truth-Out, October 4.

Giroux, Henry A. 2013. The Occupy Movement Meets the Suicidal State: Neoliberalism and the Punishing of Dissent. Situations: Project of the Radical Imagination 5 (1). http://ojs.gc.cuny.edu/index.php/situations/article/viewFile/1432/1467 
Haywood, James. 2011. The Significance of Millbank. Springtime: Springtime: The New Student Rebellions, London: Verso.

Headlam, Cecil. 1912. Oxford and Its Story. Second. London: J.M. Dent and Sons, Ltd. https://archive.org/stream/oxforditsstory00headuoft\#page/n267/mode/2up/search/Vesper

Hoefferle, Caroline. 2012. British Student Activism in the Long Sixties. Vol. 9. Routledge.

Hoyland, John. 2008. Power to the People. The Guardian, March 15, sec. World news. https://www.theguardian.com/music/2008/mar/15/popandrock.pressandpublishing

Ibrahim, Joseph. 2011. The New Toll on Higher Education and the UK Student Revolts of 2010-2011. Social Movement Studies: Journal of Social, Cultural and Political Protest, 415-21. doi:10.1080/14742837.2011.614110.

Ibrahim, Yousaf. 2010. Between Revolution and Defeat: Student Protest Cycles and Networks. Sociology Compass 4 (7): 495-504.

Jongbloed, Ben. 2003. Marketisation in Higher Education, Clark's Triangle and the Essential Ingredients of Markets. Higher Education Quarterly 57 (2): 110-35.

Lazzeretti, Luciana, and Ernesto Tavoletti. 2006. Governance Shifts in Higher Education: A Cross-National Comparison. European Educational Research Journal 5 (1): 18-37. doi:10.2304/eerj.2006.5.1.18.

Lorenz, Chris. 2006. Will the Universities Survive the European Integration? Higher Education Policies in the EU and in the Netherlands before and after the Bologna Declaration. Sociologia Internationalis 44 (1): 123.

Maireder, Axel, and Christian Schwarzenegger. 2012. A Movement of Connected Individuals. Information, Communication \& Society 15 (2): 171-95. doi:10.1080/1369118X.2011.589908.

Marsh, Alan. 1977. Protest and Political Consciousness. Sage Publications (CA).

Miller, Carol, M. 1993. THE ST. SCHOLASTICA DAY RIOT OXFORD AFTER THE BLACK DEATH. FCH Annals - Journal of the Florida Conference of Historians 1 (June): 29-42.

Molesworth, Mike, Richard Scullion, and Elizabeth Nixon. 2010. The Marketisation of Higher Education. Routledge.

Parkin, Frank. 1968. Middle Class Radicalism. Manchester.

Perry, Matt. 2008. May 1968 across the Decades - International Socialism, March 31. http://isj.org.uk/may-1968-across-the-decades/\#118perry 35

Power, Nina. 2012. Dangerous Subjects: UK Students and the Criminalization of Protest. South Atlantic Quarterly 111 (2): 412-20.

Rahona Lopez, Marta Mercedes. 2008. La Educacion Universitaria En Espana Y La Insercion Laboral de Los Graduados En La Decada de Los Noventa. Un Enfoque Comparado. Madrid: Universidad Autonoma de Madrid.

Rodriguez-Amat, Joan Ramon and Cornelia Brantner. 2014. "Space and Place Matters: A Tool for the Analysis of Geolocated and Mapped Protests." New Media \& Society. September. doi:10.1177/1461444814552098.

Richards, Huw. 1997. The Collision of Two Worlds. Times Higher Education (THE), December 5. https://www.timeshighereducation.com/news/the-collision-of-twoworlds 1104836 .article

Ruegg, Walter, ed. 2010. A History of the University in Europe: Volume 4, Universities since 1945 -. Cambridge: Cambridge University Press.

Scott, Peter. 2012. It's 20 Years since Polytechnics Became Universities - and There's No Going Back. The Guardian, September 3. http://www.theguardian.com/education/2012/sep/03/polytechnics-became-universities1992-differentiation.

Smelser, N. 1968. Essays in Social Explanation. Prentice Hall.

Soloveitchik, Rina. 2016. Judith Butler: 'Trump Is Emancipating Unbridled Hatred.' Die Zeit, October 28, sec. Kultur. http://www.zeit.de/kultur/2016-10/judith-butler-donald-trumppopulism-interview

Swain, Dan. 2011. The Student Movement Today. International Socialism 130: 95-112. 
Tamcke, Martin, Janny de Jong, Lars Klein, and Margriet van der Waal, eds. 2013. Europe Space for Transcultural Existence? Studies in Euroculture, volume 1. Göttingen: Universitätsverlag Göttingen.

Taylor, Diane. 2016. University Students across London Take Part in Rent Strike. The Guardian, May 6. http://www.theguardian.com/education/2016/may/06/universitystudents-across-london-take-part-in-rent-strike

Tharoor, Ishaan. 2013. Viewpoint: Why Was the Biggest Protest in World History Ignored? Time, February 15.

Thomas, Nick. 2002. Challenging Myths of the 1960s: The Case of Student Protest in Britain. Twentieth Century British History 13 (3): 277-97. doi:10.1093/tcbh/13.3.277.

Toret, Javier. 2013. Technopolitics: The Potential of Connected Multitudes. The 15M Network-System as a New Paradigm of Distributed Politics. Barcelona: Universitat oberta de Catalunya. https://datanalysis $15 \mathrm{~m}$.files.wordpress.com/2013/06/technopolitics-15msummary.pdf

Treré, Emiliano. 2012. Social Movements as Information Ecologies: Exploring the Coevolution of Multiple Internet Technologies for Activism. International Journal of Communication 6: 19.

Treré, Emiliano. 2016. The Dark Side of Digital Politics: Understanding the Algorithmic Manufacturing of Consent and the Hindering of Online Dissidence. IDS Bulletin 41 (1): 127-38. doi:10.19088/1968-2016.111.

Van Vught, Frans A. 1989. Governmental Strategies and Innovation in Higher Education. Higher Education Policies Series, 7. ERIC.

Walgrave, Stefaan, and Joris Verhulst. 2003. The February 15 Worldwide Protests against a War in Iraq: An Empirical Test of Transnational Opportunities. Outline of a Research Programme. In International Workshop on Contemporary Anti-War Mobilizations, Agonistic Engagement Within Social Movement Networks, Corfu, Greece.

Ward's Book of Days. 2006. St Scholastica Day Riot. http://www.wardsbookofdays.com/10february.htm

Wollter, Andrä. 2004. From State Control to Competition. The Canadian Journal of Higher Education XXXIV (3).

Woodcock, James. 2013. The National Union of Students and the Left. The Oxford Left Review. February 24. https://oxfordleftreview.com/olr9-3/

\section{About the Authors}

Joan Ramon Rodriguez-Amat

Senior Lecturer and Course Leader for the BA. Media (Hons) in Sheffield Hallam University since June 2015. Before that he spent four years as a Postdoc at the University of Vienna (Austria) and taught in universities in Spain, France, Germany and Austria a part from the United Kingdom. He obtained his PhD in 2010 at the University Autonoma de Barcelona (Spain). His current work turns around the Governance of communicative spaces and times and the technologies that operate it. Address: Cantor Building, Sheffield Hallam University, 153, Arundel Street, S1 2NU Sheffield , United Kingdom. [email: mon.rodriguez@shu.ac.uk]

\section{Bob Jeffery}

Senior Lecturer in Sociology and Course Leader for the MRes Social Sciences in the Department of Psychology, Sociology and Politics at Sheffield Hallam University. His research interests include social class, work and employment, urban studies, trade unions, social movements and policing. Recent published work has included an examination of the 2011 Salford Riot, a history of public order policing in Greater Manchester and an analysis of modes of belonging in a gentrifying inner-city neighbourhood. His current research examines precarious employment, punitive welfare reform and class identities in post-recession Salford. Address: 2.06 HOTC, Collegiate Crescent Campus, Sheffield Hallam University, S10 2BQ [email: r.f.jeffery@shu.ac.uk] 